\title{
The clinical variability of midbrain lesions
}

The midbrain is a crucial part of the central nervous system. In a small volume, it not only contains the nuclei of the oculomotor nerves ${ }^{[1]}$ (III and IV cranial nerves) but it is also crossed by many structures coming from the cerebral hemispheres, the cerebellum, and from the periphery. The midbrain also contains an important structure such as the red nucleus, the substantia nigra, and the superior cerebellar peduncle among others. Hence, it is easy to understand how different lesions in this area can lead to such a great variability in clinical presentation. ${ }^{[2]}$

The midbrain can be involved in many different pathological process such as vascular accident (Weber's syndrome, Parinaud's syndrome with the typical upward gaze palsy), tumors (one of the first patients described as affected by supranuclear progressive palsy was instead affected by brainstem tumor), demyelinating processes (multiple sclerosis), infections, and neurodegenerative diseases (Parkinson's disease and supranuclear progressive palsy). Each one of these conditions can present with a broad clinical spectrum, from movement disorder to focal signs. One of the key symptoms is definitely the involvement of the third cranial nerve and often there is also the involvement of the conjugate upward gaze. The classic syndrome with this type of symptom is the supranuclear progressive palsy where the upward gaze palsy is one of the strongest symptoms for the diagnosis. ${ }^{[3]}$

In the paper "Bilateral ptosis without upward gaze palsy-unusual presentation of midbrain tuberculoma," ${ }^{[4]}$ Sarkar et al. describe a very interesting case of a young patient affected by midbrain tuberculoma with ataxia and ptosis. Neurotuberculosis is found in more or less $5-15 \%$ cases of extrapulmonary tuberculosis and common locations are cerebral and cerebellar hemisphere, instead brainstem locations are very rare. Brainstem tuberculomas were already described in literature with a wide range of clinical presentations such as "one and half syndrome," "eight and half syndrome," and "bilateral ptosis" as the readers will be able to find in reading the paper of the authors. In many of these case reports, the lesions were located in the midbrain showing how much can be variable the clinical presentation of a lesion affecting the midbrain.

The paper is very interesting because the authors highlight the structure of the midbrain, especially the area where the oculomotor nucleus lies and its architecture. As well described in the text, due to the particular structure of the affected area of the midbrain with tuberculoma, it is rare that there is a bilateral ptosis without upward gaze palsy. Moreover, they show how the complexity of the midbrain can lead to a heterogeneous combination of symptom in this case with ataxia.

They showed the importance of the magnetic resonance spectroscopy in the diagnosis of tuberculoma as this condition has a particular spectroscopy pattern, and it is very helpful in the differential diagnosis between this and other pathological conditions.

The authors demonstrate the importance of the right therapy. In fact, after few days, the therapy was started; the patient got better till a complete regression of his neurological deficits.

Pacei Federico

Department of Neurology, Stroke Unit, IRCCS Policlinico San Donato, San Donato Milanese, Milan, Italy

Address for correspondence: Dr. Pacei Federico, Department of Neurology, Stroke Unit, IRCCS Policlinico San Donato, San Donato Milanese, 20097 Milan, Italy. E-mail: federico.pacei@gmail.com

\section{References}

1. Strupp M, Kremmyda O, Adamczyk C, Böttcher N, Muth C, Yip CW, et al. Central ocular motor disorders, including gaze palsy and nystagmus. J Neurol 2014;261 Suppl 2:S542-58.

2. Choi YJ, Lee SH, Park MS, Kim BC, Kim MK. Midbrain infarction presenting with monocular elevation palsy and ptosis: Topographic lesion analysis. J Neuroophthalmol 2015;35:175-8.

3. Steele JC, Richardson JC, Olszewski J. Progressive supranuclear palsy. A heterogeneous degeneration involving the brain stem, basal ganglia and cerebellum with vertical gaze and pseudobulbar palsy, nuchal dystonia and dementia. Arch Neurol 1964;10:333-59. 
4. Sarkar S, Patra C, Dasgupta MK. Bilateral ptosis without upward gaze palsy - Unusual presentation of midbrain tuberculoma. J Neurosci Rural Pract 2017;8:129-32.
This is an open access article distributed under the terms of the Creative Commons Attribution-NonCommercial-ShareAlike 3.0 License, which allows others to remix, tweak, and build upon the work non-commercially, as long as the author is credited and the new creations are licensed under the identical terms.

\begin{tabular}{|l|l|}
\hline \multicolumn{2}{|c|}{ Access this article online } \\
\hline Quick Response Code: & Website: \\
\hline & www.ruralneuropractice.com \\
\cline { 2 - 2 } & \\
\hline & \\
\hline
\end{tabular}

How to cite this article: Federico $P$. The clinical variability of midbrain lesions. J Neurosci Rural Pract 2017;8:5-6.

\section{Author Help: Online submission of the manuscripts}

Articles can be submitted online from http://www.journalonweb.com. For online submission, the articles should be prepared in two files (first page file and article file). Images should be submitted separately.

1) First Page File:

Prepare the title page, covering letter, acknowledgement etc. using a word processor program. All information related to your identity should be included here. Use text/rtf/doc/pdf files. Do not zip the files.

2) Article File:

The main text of the article, beginning with the Abstract to References (including tables) should be in this file. Do not include any information (such as acknowledgement, your names in page headers etc.) in this file. Use text/rtf/doc/pdf files. Do not zip the files. Limit the file size to $1 \mathrm{MB}$. Do not incorporate images in the file. If file size is large, graphs can be submitted separately as images, without their being incorporated in the article file. This will reduce the size of the file.

3) Images:

Submit good quality color images. Each image should be less than $4096 \mathrm{~kb}(4 \mathrm{MB})$ in size. The size of the image can be reduced by decreasing the actual height and width of the images (keep up to about 6 inches and up to about $1800 \times 1200$ pixels). JPEG is the most suitable file format. The image quality should be good enough to judge the scientific value of the image. For the purpose of printing, always retain a good quality, high resolution image. This high resolution image should be sent to the editorial office at the time of sending a revised article.

4) Legends:

Legends for the figures/images should be included at the end of the article file. 